\title{
ISOLATION OF SHIGA TOXIGENIC ESCHERICHIA COLI FROM BUTCHERIES IN TAQUARITINGA CITY, STATE OF SÃO PAULO, BRAZIL
}

\author{
Daniela Rodolpho ${ }^{1}$ José Moacir Marin²* \\ ${ }^{1}$ Faculdade de Ciências Agrárias e Veterinárias de Jaboticabal, Universidade Estadual Paulista, SP, Brasil; \\ ${ }^{2}$ Departamento de Morfologia, Estomatologia e Fisiologia, Faculdade de Odontologia de Ribeirão Preto, Universidade \\ de São Paulo, Ribeirão Preto, SP, Brasil
}

Submitted: January 3, 2007; Returned to authors for corrections: May 31, 2007; Approved: September 28, 2007.

\begin{abstract}
Shiga toxigenic Escherichia coli (STEC) has been implicated as the cause of several human diseases. Samples (ground beef, grinding-machines and human hands) from 23 butcheries were assayed for E. coli using standard microbiological methods, and 287 isolates were submitted to polymerase chain reaction for the detection of stx 1, stx 2 and eae genes. Four STEC isolates were recovered, two from ground beef and two from grinding-machines; all harbored the stx 2 gene and were negative for the eae gene. All E. coli isolates including the four STEC were screened for antibiotic resistance. High levels of resistance against several antimicrobial agents were detected; those most commonly observed were to tetracycline (76.6\%), amoxicillin $(64.1 \%)$ and cephalothin $(58.8 \%)$. Such high levels of antimicrobial resistance highlight the need for a more rational use of these agents in cattle.
\end{abstract}

Key words: Escherichia coli, STEC, stx 2, antibiotic resistance, ground beef, cattle

\section{INTRODUCTION}

Shiga toxigenic Escherichia coli (STEC) has been implicated as the cause of several human diseases including mild or severe bloody diarrhea (hemorrhagic colitis), hemolytic syndrome (HUS) and renal failure $(10,22)$. The STEC strain most frequently associated with clinical disease in the United States and Europe is the serotype O157:H7 $(4,16)$. However, several other serotypes have been associated with severe disease outbreaks, and in some countries they have been isolated from clinical cases more often than $\mathrm{O} 157(13,16)$. Cattle is considered the primary reservoir of both $\mathrm{O} 157$ and non-O157 STEC bacteria (2). Several human infections have been linked to STEC in undercooked ground beef (10). During processing, fecal contamination of the carcass or transfer of bacteria found on the animal hide to the carcass could facilitate transmission of STEC to food $(4,6)$.

Pathogenic STEC strains known to produce one or two toxins resembling those from Shigella dysenteriae (19), are Shiga Toxin
1 (Stx 1) and Shiga Toxin 2 (Stx 2). Although different proteins, encoded by different genes (stx 1 and stx 2 , respectively), they have similar biological activities (18). Strains possessing stx 2 are potentially more virulent than those carrying stx 1 or even strains carrying both stx 1 and stx $2(3,16)$. Another virulence factor, intimin (eae) is encoded in a pathogenicity island called LEE (locus of enterocyte effacement). LEE-encoded genes appear to enhance STEC virulence and have been associated with severe human disease (13).

Antimicrobial agents for therapy or prophylaxis aimed at animal growth promotion, have favored propagation of resistant bacteria (27). Intestinal resistant bacteria due to fecal contamination during slaughtering may be transferred to meat products (6). If subsequently transmitted to human food (27), they become reason for concern.

This study is aimed at the determination of STEC occurrence in ground beef and the characterization of antimicrobial resistance of E. coli isolated from ground beef, meat-grinding machines and hands of meat manipulators.

*Corresponding Author. Mailing address: Faculdade de Odontologia de Ribeirão Preto, Departamento de Morfologia, Estomatologia e Fisiologia, FORP

- Via do Café S/N, Campus USP, 14040-904 Ribeirão Preto, SP, Brasil. Tel.: +55-16-36024101 Fax: +55-16-36330999. E-mail: jmmarin@ forp.usp.br 


\section{MATERIALS AND METHODS}

\section{Sampling}

Meat samples and swabs from grinding-machines and hands of meat manipulators were collected on separate occasions, over a 10-month period (March 2004 to January 2005), from twenty-three butcheries in Taquaritinga, a city in the northwest of the State of São Paulo. Samples were kept on ice between collection and testing. On the same day of collection, $25 \mathrm{~g}$ samples of ground meat were homogenized by hand in $225 \mathrm{ml}$ of sterile $0.1 \%$ (wt/vol) peptone water (Oxoid Ltd, Basingstoke, Hampshire, UK), in a stomacher bag, for 5-10 min. Swabs from machines or hands of operators were manually mixed with $10 \mathrm{ml}$ of $0.1 \%$ peptone water. One $\mathrm{ml}$ samples from each suspension were diluted in $9 \mathrm{ml}$ of lauryl sodium sulfate broth (Difco Laboratories, Detroit, USA) and incubated for $24-48 \mathrm{~h}$ at $35^{\circ} \mathrm{C}$. One hundred $\mu \mathrm{l}$ samples from tubes showing bacterial growth were added to $5 \mathrm{ml}$ of Brilliant Green broth (Difco) or EC broth (Difco) and incubated as above. Ten $\mu \mathrm{l}$ of the broths positive for coliform growth were plated on Eosin Metylene Blue (EMBDifco) agar and incubated for $24 \mathrm{~h}$ at $35^{\circ} \mathrm{C}$. At least five colonies were taken from the EMB plates for further identification (7).

\section{Determination of $s t x$ genes}

$E$. coli isolates were grown overnight in nutrient broth (Sigma Chemical Co, St Louis, USA) at $37^{\circ} \mathrm{C}$, and tested for stx genes (stx 1 and stx 2) using the polymerase chain reaction (PCR) protocol of Orden et al. (20). DNA templates were prepared by pelleting $1 \mathrm{ml}$ of each culture by centrifugation $(12000 \mathrm{xg})$, ressuspension in $250 \mu \mathrm{l}$ of sterile distilled water and boiling for $10 \mathrm{~min}$. After centrifugation, supernatants were used for PCR in an Eppendorf Mastercycler (Eppendorf AG, Hamburg, Germany). The amplified DNA products were separated by electrophoresis on $1.5 \%$ agarose gel, stained with ethidium bromide and detected under ultraviolet light. Reference E. coli strains used as controls were EDL 933 (O157:H7, stx1, stx 2, eae) and DH5 $\alpha$ (negative control).

\section{Characterisation of isolates}

Isolates were confirmed as stx+ and tested for accessory virulence marker (eae) using the PCR protocol of China et al. (5).

\section{O157 latex agglutination}

STEC isolates were serotyped for the O serotype 0157 using the O157 Latex Agglutination test kit (Oxoid, Basingstoke, Hampshire, UK). The EDL 933 strain was used as a positive control. Strains negative for agglutination were considered non-O157.

\section{Antibiotic susceptibility tests}

STEC and non-STEC isolates were submitted to the disk diffusion method according to National Committee for Clinical
Laboratory Standards (17), using commercial disks (Cefar, São Paulo, Brazil), loaded as follows: nalidixic acid ( $30 \mu \mathrm{g})$, amikacin $(30 \mu \mathrm{g})$, amoxicillin $(10 \mu \mathrm{g})$, amoxicillin-clavulanic acid $(30 \mu \mathrm{g})$, ampicillin $(10 \mu \mathrm{g})$, cephalothin $(30 \mu \mathrm{g})$, ceftriaxone $(30 \mu \mathrm{g})$, ciprofloxacin $(5 \mu \mathrm{g})$, cotrimoxazole $(25 \mu \mathrm{g})$, streptomycin $(10$ $\mu \mathrm{g})$, gentamicin $(10 \mu \mathrm{g})$ and tetracycline $(30 \mu \mathrm{g})$. E. coli reference strains ATCC 25922 and ATCC 35218 were used for strain quality control.

\section{RESULTS}

Among 287 E. coli isolates submitted to PCR to detect stx 1 , stx 2 and eae genes, four STEC strains were isolated. Two of them were from the same butchery (ground beef and grindingmachine) and the remaining two (one from ground beef and one from a grinding-machine) were from two different stores (Table 1). All isolates carried the stx 2 gene and were negative for the presence of eae gene.

Antibiotic resistance patterns of the isolates $(n=287)$ are presented in Table 2. Isolates presenting intermediary resistance were also classified as resistant. The most frequent resistances were to tetracycline, amoxicillin, cephalothin and streptomycin. Resistances to amoxicillin + clavulanic acid and ceftriaxone were rare. Thirty (10.4\%) isolates were sensitive to all antibiotics tested.

Resistance to at least three drugs was found in $67.0 \%$ of the isolates and $22.0 \%$ were resistant to more than 6 antibiotics. The resistance patterns of the STEC isolates are presented in Table 3. One of the isolates (strain 530) was resistant to 7 antibiotics; another (strain 426) was susceptible to all drugs.

Table 1. Isolation of STEC from butcheries in Taquaritinga city, State of São Paulo, Brazil.

\begin{tabular}{lccc}
\hline \multicolumn{1}{c}{ Origin } & $\begin{array}{c}\text { Examined } \\
\text { samples }\end{array}$ & $\begin{array}{c}\text { Positive } \\
\text { samples (\%) }\end{array}$ & $\begin{array}{c}\text { stx } \\
\text { genotype }\end{array}$ \\
\hline Ground beef & 91 & $2(2.1)$ & stx 2 \\
Manipulator hands & 42 & 0 & 0 \\
Grinding-machines & 154 & $2(1.2)$ & stx 2 \\
\hline
\end{tabular}

\section{DISCUSSION}

STEC strains are part of the microbiota of the gastrointestinal tract of cattle raised for meat consumption. Transfer of fecal material to carcasses at slaughter leads to potential contamination of raw meat (6), as also does cross-contamination of meat and processing equipment (1).

All STEC isolated in this study carried the stx 2 gene, in agreement with Brazilian $(11,14)$ and Argentinean reports (21) showing that stx 2 is more frequent than stx 1 in cattle. Absence 
Table 2. Antibiotic resistance of 287 E. coli isolates recovered from ground beef, grinding-machines and hands of meat manipulators in 23 butcheries in a Taquaritinga city, State of SãoPaulo, Brazil.

\begin{tabular}{lcc}
\hline \multirow{2}{*}{ Antibiotic } & \multicolumn{2}{c}{ Resistant strains * } \\
\cline { 2 - 3 } & $\mathrm{n}$ & $\%$ \\
\hline Tetracycline & 220 & 76.6 \\
Amoxicillin & 184 & 64.1 \\
Cephalothin & 169 & 58.8 \\
Streptomycin & 147 & 51.2 \\
Nalidixic acid & 90 & 31.3 \\
Ampicillin & 68 & 23.6 \\
Amikacin & 47 & 16.3 \\
Ciprofloxacin & 44 & 15.3 \\
Cotrimoxazole & 35 & 12.2 \\
Gentamicin & 28 & 9.7 \\
Ceftriaxone & 21 & 7.3 \\
Amoxicillin + clavulanic acid & 10 & 3.4 \\
\hline
\end{tabular}

*Isolates presenting full and intermediary resistance were combined and considered resistant.

Table 3. Resistance patterns of the four STEC isolates recovered from butcheries.

\begin{tabular}{cl}
\hline Isolate & \multicolumn{1}{c}{ Resistance pattern* } \\
\hline 426 & none $* *$ \\
393 & amox * \\
883 & nalid; ceph; amox; tet \\
530 & cipro; amik; amp; nalid; ceph; amox; tet \\
\hline
\end{tabular}

*-amox- amoxicillin; nalid- nalidixic acid; ceph- cephalothin; tettetracycline; cipro- ciprofloxacin; amik- amikacin; amp- ampicillin.

**- Susceptible to all tested antibiotics.

or rarity of the eae gene in STEC isolates coincides with earlier reports $(11,14)$. Absence of serotype O157: H7 in STEC isolates is not unexpected; it is extremely rare $(0.6 \%)$ in Brazilian cattle (11). Interestingly, two recovered isolates did not express stx genes (11).

Hussein and Bollinger (10), in a review of the prevalence of STEC in beef, reported prevalence of non-O157 STEC ranging between $1.7 \%$ and $58.0 \%$ in samples from packing plants and between $3.0 \%$ and $62.5 \%$ in supermarket samples; the USA, England, Canada and India showed the highest frequencies on isolation. In the present study, we found $1.3 \%$, a value lower than those reported earlier (11).

Two of the STEC isolates, strains 393 and 426, were recovered from the same butchery, one from ground beef and the other from a meat-grinding machine. This is a matter of concern because unsatisfactory cleaning of meat grinders have been proven to be a source of contamination during processing $(1,8)$. Warriner et al. (26) demonstrated that the same clone of E. coli was isolated from a pork carcass and from the equipment used during the carcass processing.

The emergence and dissemination of antimicrobial resistance among E. coli, especially STEC strains from cattle, may have potentially negative clinical implications for humans. Thus continued surveillance of emerging antimicrobial resistance among zoonotic food-borne pathogens, including STEC is required to ensure public health protection. Although STEC O157: H7 had been considered sensitive to many antibiotics (24), recent results demonstrated resistance of STEC O157:H7, and in special the non-O157 STEC strains $(9,12)$. Results of antimicrobial susceptibility testing (Table 2) showed high resistance to tetracycline, cephalothin, amoxicillin and streptomycin. These findings agree with data from previous studies showing that resistance is common among strains isolated from food, animals and meat $(23,25)$.

Despite of low number of non-O157 STEC strains isolated in the present study $(n=4)$ some of these strains (Table 3) were resistant to four or more antibiotics, in agreement with the recent report of Mora et al. (15), who described that among 581 nonO157 STEC strains, 239 (41.0\%) were resistant to at least one of the antibiotics tested. These authors detected multiple resistance in 71 strains, which were resistant to five or more antimicrobial agents.

Antimicrobial-resistant bacteria in food may be a source of resistance genes transferable to human intestinal microbiota (28). Control strategies should therefore be introduced by veterinary authorities to safeguard public health.

\section{ACKNOWLEDGEMENTS}

The authors thank Tania Marques da Silva for technical assistance. Financial support was from FAPESP.

\section{RESUMO}

\section{Isolamento de Escherichia coli Shiga toxigênica em açougues na cidade de Taquaritinga, Estado de São Paulo, Brasil}

Escherichia coli Shiga toxigênica (STEC) tem sido responsabilizada como o agente etiológico de diversas doenças nos seres humanos. Neste estudo foram analisadas amostras provenientes de 23 açougues (carne moída, moedor de carne e mãos de manipuladores) visando o isolamento de cepas de $E$. coli utilizando os métodos microbiológicos tradicionais. Um total de 287 cepas de E. coli, isoladas destas amostras, foram submetidas a reação em cadeia da polimerase para a detecção 
dos genes stx 1 , stx 2 e eae. Foram identificadas 4 cepas STEC, 2 provenientes de carne moída e 2 provenientes do moedor de carne, todas as cepas apresentando o gene stx 2 e negativas para a presença do gene eae. Todas as cepas de E. coli, incluindo as 4 cepas STEC, foram examinadas para verificar a resistência antimicrobiana. Foram detectados altos níveis de resistência a diferentes agentes antimicrobianos, sendo as resistências mais elevadas para a tetraciclina $(76,6 \%)$, amoxicilina $(64,1 \%)$ e cefalotina $(58,8 \%)$. Estes altos índices de resistência ressaltam a necessidade de uma utilização mais racional destes agentes no gado bovino.

Palavras-chave: Escherichia coli, STEC, stx 2, resistência a antibióticos, carne moída, gado

\section{REFERENCES}

1. Aslam, M.; Greer, G.G.; Nattress, F.M.; Gill, C.O.; McMulen, L.M. (2004). Genotypic analysis of Escherichia coli recovered from product and equipment at a beef-packing plant. J. Appl. Microbiol., 97, 78-86.

2. Bettelheim, K.A. (2000). Role of non-O157 VTEC. J. Appl. Microbiol., 88, 38S-50S.

3. Boerlin, P.; McEwen, S.A.; Boerlin-Petzold, F.; Wilson, J.B.; Johnson, R.P.; Gyles, C.L. (1999). Association between virulence factors of Shiga toxin-producing Escherichia coli and disease in humans. $J$. Clin. Microbiol., 37, 497-503.

4. Caprioli, A.; Morabito, S.; Brugere, H.; Oswald, E. (2005). Enterohaemorrhagic Escherichia coli: emerging issues on virulence and modes of transmission. Vet. Res., 36, 289-311.

5. China, B.; Pirson, V.; Mainil, J. (1996). Typing of bovine attaching and effacing Escherichia coli by multiplex in vitro amplification of virulence-associated genes. Appl. Environ. Microbiol., 62, 34623465.

6. Elder, R.O.; Keen, J.E.; Siragusa, G.R.; Barkocy-Gallagher, G.A.; Koohmaraie, M.; Laegreid, W.W. (2000). Correlation of enterohemorrhagic Escherichia coli $\mathrm{O} 157$ prevalence in feces, hides, and carcasses of beef cattle during processing. Proc. Nat. Acad. Sci. USA 97, 2999-3003.

7. Farmer, J.J. (1999). Enterobacteriacea: Introduction and Identification. In: Murray, P.R., Baron, E.J., Phaler, M.A., Tenover, F.C., Yolken, R.H., (Eds). Man. Clin. Microbiol., 7 ed., ASM, Press, Washington.

8. Farrel, A.B.; Ronner, A.B.; Wong, A.C.I. (1998). Attachment of Escherichia coli O157: $\mathrm{H} 7$ in ground beef to meat grinders and survival after sanitation with chorine and peroxyacetic acid. J. Food Prot., 61, 817-822.

9. Galland, J.C.; Hyatt, D.R.; Crupper, SS.; Acheson, D.W. (2001). Prevalence, antibiotic susceptibility, and diversity of Escherichia coli O157: H7 isolates from a longitudinal study of beef feedlots. Appl. Environ. Microbiol., 67, 1619-1627.

10. Hussein, H.S.; Bollinger, L.M. (2005). Prevalence of Shiga toxinproducing Escherichia coli in beef. Meat Sci., 71, 676-689.

11. Irino, K.; Kato, M.A.M.F.; Vaz, T.M.M.I.; Ramos, I.I.; Souza, M.A.C.; Cruz, A.S.; Gomes, T.A.T.; Vieira, M.A.M.; Guth, B.E.C. (2005). Serotypes and virulence markers of Shiga toxin-producing Escherichia coli (STEC) isolated from dairy cattle in São Paulo State, Brazil. Vet. Microbiol., 105, 29-36.
12. Khan, A.; Das, S.C.; Ramamurthy, T.; Sikdar, A.; Khanam, J.; Yamasaki, S.; Takeda, Y.; Balakrish Nair, G. (2002). Antibiotic resistance, virulence gene and molecular profiles of Shiga Toxinproducing Escherichia coli isolates from diverse sources in Calcutta, India. J. Clin. Microbiol., 40, 2009-2015.

13. Law, D. (2000). Virulence factors of Escherichia coli $\mathrm{O} 157$ and other Shiga toxin-producing E. coli. J. Appl. Microbiol., 88, 729745.

14. Lira, M.W.; Macedo, C.; Marin, J.M. (2004). The incidence of Shiga toxin-producing Escherichia coli in cattle with mastitis in Brazil. $J$. Appl. Microbiol., 97, 861-866.

15. Mora, A.; Blanco, J.E.; Blanco, M.; Alonso Pilar, M.; Dhabi, G.; Echeita, A.; Gonzalez, E.A.; Bernardez, M.I.; Blanco, J. (2005). Antimicrobial resistance of Shiga toxin (verotoxin)-producing Escherichia coli O157: H7 and non-O157 strains isolated from humans, cattle, sheep and food in Spain. Res. Microbiol., 156, 793806.

16. Nataro, J.P.; Kaper, J.B. (1998). Diarrhoeagenic Escherichia coli. Clin. Microbiol. Rev., 11, 142-201.

17. National Committee for Clinical Laboratory Standards. (2000). Performance Standards for Antimicrobial Disk Susceptibility Tests, seventh ed., Approved Standard M2-A7. Comm. Clin. Lab. Stand., Wayne, PA.

18. Neil, M.A. (1997). Overview of Verotoxigenic Escherichia coli. J. Food Prot., 60, 1444-1446.

19. O'Brien, A.D.; Holmes, R.K. (1987). Shiga and Shiga-like toxins. Microbiol. Ver., 51, 206-220.

20. Orden, J.A.; Ruiz-Santa-Quiteria, J.A.; Cid, D.; Garcia, S.; Sanz, R.; de la Fuente, R. (1998). Verotoxin-producing Escherichia coli (VTEC) and eae-positive non-VTEC in 1-30-days-old diarrhoeic dairy calves. Vet. Microbiol., 63, 239-248.

21. Padola, N.L.; Sanz, M.E.; Blanco, J.E.; Blanco, M.; Blanco, J.; Etcherria, A.I.; Arroyo, G.H.; Usera, M.A.; Parma, A.E. (2004). Serotypes and virulence genes of bovine Shigatoxigenic Escherichia coli (STEC) isolated from a feedlot in Argentina. Vet. Microbiol., 100, 3-9.

22. Paton, J.C.; Paton, A.W. (1998). Pathogenesis and diagnosis of Shiga toxin-producing Escherichia coli infections. Clin. Microbiol. Rev., 11, 450-479.

23. Sáenz, Y.; Zarazaga, M.; Brinas, L.; Lantero, M.; Ruiz-Larrea, F.; Torres, C. (2001). Antibiotic resistance in Escherichia coli isolates obtained from animals, foods and humans in Spain. Int. J. Antimicrob. Agents, 18, 353-358.

24. Schmidt, H.; von Maldeghem, J.; Frosch, M.; Karch, H. (1998). Antibiotic susceptibilities of verocytotoxin-producing Escherichia coli O157 and non-O157 during 1996. J. Antimicrob. Chemother, 42, 548-550.

25. Schroeder, C.M.; White, D.G.; Ge, B.; Zhang, Y.; McDermott, P.F.; Ayers, S.; Zhao, S.; Meng, J. (2003). Isolation of antimicrobialresistant Escherichia coli from retail meats purchased in Greater Washington, DC, USA. Int. J. Food Microbiol., 85, 197-202.

26. Warriner, K.; Aldsworth, T.G.; Kaur, S.; Dodd, C.E.E. (2002). Crosscontamination of carcasses and equipment during pork processing. J. Appl. Microbiol., 93, 169-177.

27. White, D.G.; Zhao, S.; Simjee, S.; Wagner, D.D.; McDermott, P.F. (2002). Antimicrobial resistance of foodborne pathogens. Microb. Infect., 4, 405-412.

28. Winokur, P.L.; Vonstein, D.L.; Hoffman, L.J.; Uhlenhopp, E.K.; Doern, G.V. (2001). Evidence for transfer of CMY-2 AmpC $\beta$ lactamase plasmids between Escherichia coli and Salmonella isolates from food animals and humans. Antimicrob. Agents Chemother, 45, $2716-2722$. 